\title{
The Effect of Corporate Governance Mechanisms on Banks Performance Using GLS: The Case From Kenya
}

\author{
Nahifa Said SOUD iD Nevzat AYPEK (iD b \\ a Ankara Hacı Bayram Veli University, Institute of Graduate Programs, Accounting and Financing, Phd Program, Ankara, Turkey. \\ snahifa90@gmail.com \\ b Ankara Hacı Bayram Veli University, Faculty of Economic and Administrative Sciences, Ankara, Turkey. nevzat.aypek@hbv.edu.tr
}

\begin{tabular}{|c|c|}
\hline ARTICLE INFO & ABSTRACT \\
\hline Keywords: & Purpose - This study examines the effect of corporate governance mechanisms on bank performance of \\
\hline Corporate governance & Kenya commercial banks. \\
\hline Bank performance & Design/Methodology/Approach - For examining the aim of this research the empirical research was \\
\hline Generalized least square & conducted on Kenya Commercial Banks. The data of this study was collected from the annual reports of \\
\hline 3SLS & each bank. The sample used in the analysis was sixteen commercial banks covering the period 2010-2019. \\
\hline Kenya & $\begin{array}{l}\text { Corporate governance variables are represented by board size, NEDs, number of committees, number of } \\
\text { board meetings, and the size of audit committees, while performance was measured using ROA and ROE. }\end{array}$ \\
\hline Received 9 October 2021 & The collected data was analyzed using STATAMP13 to test the suggested hypotheses. The three least \\
\hline Revised 10 December 2021 & square 3SLS and generalized least square were used to analyze the obtained data. \\
\hline \multirow[t]{2}{*}{ Accepted 20 December 2021} & $\begin{array}{l}\text { Findings - The result revealed that NEDs, NBM, and leverage has a negative and significant impact on } \\
\text { banks performance, while NC and total asset has a positive significant impact. On the other hand board, } \\
\text { size and SAC have a negative and insignificant impact on bank performance. }\end{array}$ \\
\hline & Discussion - Most of the previous studies evaluated the relationships between two or three variables with \\
\hline Article Classification: & conflicting and inconsistent results and acknowledgment of its importance in companies, the subject has \\
\hline Research Article & $\begin{array}{l}\text { not received much attention in Kenya and has not been actively debated and that, Kenya have experienced } \\
\text { the lack of effective corporate governance practices. This study investigate the corporate governance } \\
\text { mechanisms on banking performance from the new perspective measurement. }\end{array}$ \\
\hline
\end{tabular}

\section{INTRODUCTION}

Good corporate governance is absolutely a situation that an organization must-have. For the organization to consider good corporate governance, it needs a good governance system that can help build shareholder confidence and ensure that all stakeholders are treated equally. A good system of corporate governance will give compelling security to investors to recuperate their investment persuasively, relevantly, and efficiently, and guarantee that management acts for the benefit of the company (Mayang Mahrani \& Noorlailie Soewarno, 2018). A series of corporate governance scandals around the world have weakened the trust in financial statements and made investors suspicious, which has caused global investors to lose confidence. (Fodio, M. I., Ibikunle, J., \& Oba, V. C, 2013). A weak corporate governance structure may provide managers with opportunities to conduct behaviors, which ultimately leads to a reduction in the quality of reported earnings, which strongly indicates a serious deterioration in business ethics (Jesus, S.G. \& Emma, G.M, 2013).

In latest years, immense accounting frauds exposed in the stock markets have all over again shown the existence of moral screw-ups and the importance of transparency and reliability of financial information provided to the stock market (Lang, M. \& Lundholm, R., 2000). The regulatory reaction to economic scandals has been to take measures to shield facts transparency, mitigate conflicts of interest and make sure the independence of auditors, all to defend the investors' interest and increase the self-assurance of capital markets (Leuz, C., Nanda, D. , \& Wysocki, P. D, 2003) 


\section{N. S. Soud - N. Aypek 13/4 (2021) 3544-3558}

As a result of the globalization of financial markets, deregulation and technological change, the question of corporate governance of financial institutions and their role in stabilizing the industry has reached new levels of significance since the mid-1990s. These positive factors, together with the poor management, corruption and fraud that has resulted in multiple financial crisis in major industrialized countries over a number of years, have brought the role of corporate governance to the fore in many countries and in the international economic community.

For better resource usage and target achievement, the African continent has come a long way in institutionalizing corporate governance in organizations through economic globalization. While corporate governance has helped to form the structure and procedures of organizations to some degree, there is still much to be done to strengthen the processes of corporate governance as it is still at the infancy stage. To enable every investor to use resources in any developing economy, there should be a sound corporate governance mechanism and good corporate performance. In most developing countries, weak governance is one of the key factors leading to the downturn in economic results, in which a larger proportion of less-performing organizations are seen in Africa (Ruparelia, R., 2016).

Before Kenya had a lack of accountability in the public sector which also led to an impact on the private sector. Moreover, inefficiency had been institutionalized (Bebchuk, L., , Cohen, A. , \& Ferrell, A., 2009). This was largely due to the lack of a corporate governance system. Despite senior government officials, owning shares in some of the few publicly traded companies, the government did not decide to commit to the implementation of safety rules. Most of the boards of directors of many listed companies consisted of friends, relations, and political associates of government officials. The situation was worsened by the fact that the NSE was under the control of family-owned and managed businesses whose driving force was business, not regulation. Thus, the NSE had a friendly relationship with listed companies and rarely invoked regulatory penalties for noncompliance with listing or membership rules (Gakeri J, K., 2013).

Many countries including Kenya have succumbed to these questionable corporate governance policies and unethical practices. Many types of research have been conducted in the study of corporate governance around the world and acknowledgment of its importance in companies, the subject has not received much attention in country like Kenya and has not been actively debated and that, Kenya have experienced the lack of effective corporate governance practices. For that reason, this study investigate the corporate governance mechanisms on banking performance from the new perspective measurement. The findings this study aims to fill this research gap by empirically examining the effect of corporate governance mechanisms on bank performance of Kenya.

\section{LITERATURE REVIEW}

Agency theory originally was stated by (Ross, S, 1973) which explains the relationship between two parties such as the board of directors and shareholders. Agency theory offers a reasonable explanation of the importance of corporate governance. It theorizes that there is conflict arising from different managers' and shareholders' interests. This may occur when the manager has a self-interest motive to make self-significant decisions and thus might harm shareholders' interest. Having good corporate governance makes available strong protection on shareholders' interest. Although, there is a separation between ownership and its control, this may create an agency problem whereby managers operate the firm aligned with their interests, and not those of shareholders (Jansen \& Meckling, 1976). This creates opportunities for managers of the company to use firm resources for the maximization of their values rather than those of the shareholders.

Most research has admitted that corporate governance can help firms to control agency problems (Daily, Dalton, \& Ca, 2003). The board is one of the major corporate governance mechanisms. The board of directors is selected according to their professional and their experience of the operating activities of the firm or their network with outside parties. However, Agency problems may arise among shareholders against bondholders, shareholders versus independent auditors, shareholders against Government, dominant versus minority shareholders, as well as management and subordinates. Also, agency theory has been shown managerial decisions incorporate risk management regarding risk-taking and hedging (Smith \& Stulz, 1985).

Ene \& Bello (2016), examined the effect of Corporate Governance on Bank's Financial Performance in Nigeria by explaining that weak corporate governance has been an essential reason for all-new episodes of crisis in the 


\section{N. S. Soud - N. Aypek 13/4 (2021) 3544-3558}

banking system The study investigated the impact of the relative size of non-executive directors and the board size on return on investment (ROA) of a sample of 10 selected banks. Secondary data were used from the Nigeria stock exchange from the period 2004-2013. The result from the ordinary least square regression technique aided by SPSS 21 revealed that the relationship between corporate governance and bank performance in Nigeria is quite significant as a unit change in the board size and the relative size of nonexecutive directors increases the return on assets. However, (Abdulazeez DA, , NdibeL , \& Mercy AM, 2016), inspected the impact of corporate governance on the financial performance of all listed deposit money banks in Nigeria for seven years after consolidation. The result through regression analysis found that a larger board size contributes emphatically and fundamentally to the deposit money in Nigerian banks. On the other hand, (Okwuchukwu; , Ezeudu, \& Patience, 2015), examined the effect of corporate governance on the performance of commercial banks in Nigeria. The findings revealed that Board Independence, Directors' Shareholding, and Audit Committee Meetings had positive and significant effects on banking sectors' performance, while Board Size showed a negative and significant effect on the performance of the banking sector in Nigeria.

Okere \& Ibidunni,(2019), investigate the effect of corporate governance on investment decisions of shareholders of listed banks in the Nigerian capital market from 2005 to 2015. The secondary data was used from the financial statements of eight listed banks. Then, Panel Regression Analysis was conducted, and the result revealed that there is a positive and significant relationship between corporate governance (board size, board independence, and audit committee independence) and investment decisions of shareholders.

Manning (2019), evaluate the impact of corporate governance on company performance. The size of the board of directors, audit committee and gender composition of the board of directors were used as a proxy of corporate governance, while the company's performance was measured by earnings before interest and tax. The data from 30 companies which consist of both large and small financial companies listed gathered in NYSE. The data being analyzed using descriptive and inferential statistics. The result reported the size of the board of directors, audit committee, and gender composition of the board of directors have some impact on the performance. The study is consistent with (R., Entebang, H., \& A., 2011) discovered a board size, board composition, and audit committee has a positive significant relationship with ROE and PM. Moreover, the board size should be limited to a considerable limit and the board of directors must be a mixture of executive and non-executive directors (R., Entebang, H., \& A., 2011).

Ahmed (2019), investigates the relationship between capital structure, ownership structure and corporate governance. This study focused on SMEs because there are less attention on this area. The result found a positive relationship for all corporate governance variables except for board size. The ownership structure is found to be positive and significantly related to capital structure. However, (Cheema, K. U. \& Din, M. S, 2013), shed some light on the relationship between the corporate governance and Firm financial performance in Cement industry of Pakistan. Three variables were used which contain board Size, Family controlled firms, and CEO duality while firm performance was measured through Return on Equity, return on assets, and earnings per share, debt to equity and current ratio. The result found out that there is a positive significant relationship between corporate governance and firm performance. Also, (Arena, S., , Kayagil, S. Ö., , \& Aydemir, S. D., 2014), investigated the determinants and effects of the corporate governance level of the firms operating in the Istanbul Stock Exchange. The study used secondary data and the sample of 162 firms traded continuously on ISE on all indexes, excluding sportive and financial indexes.The study came with the result that, there is a positive relationship between growing corporate governance implementations of the firms and the firm performance. On the other hand, (Zabria, S. M., , Ahmad, K., \& Wah, K. K, 2016), found out that board size has a weak negative link with ROA, but it has no effect on ROE. The other finding indicated that there was no relationship between board independence and firm performance.

Paul, G. D., , Ebelechukwu, E. C., , \& Yakubu, S., (2015), measured the impact of corporate governance (CG) on microfinance bank's financial performance in Nigeria. The study found out that the Board Composition (BC) and the Composition of Board Committees (CBC) have a significant relationship with banks' financial performance. Moreover, (Mahrani, M., \& Soewarno, N., 2018), determine the direct influence of the mechanism of good corporate governance (GCG) and corporate social responsibility (CSR) on financial performance as well as through earnings management as a mediating variable. The finding of the study demonstrates that the mechanism of good corporate governance and corporate social responsibility has a positive effect on financial performance as well as the CSR on financial performance. However, (Ghaffar , 2014), evaluates the impact of 


\section{N. S. Soud - N. Aypek 13/4 (2021) 3544-3558}

good corporate governance practices on the profitability of Islamic banks in Pakistan. Corporate governance measured used were ethics and corporate social responsibility. The result revealed that all these variables of corporate governance have a significant relationship with the profitability of the banks. The Islamic banks of Pakistan tend to increase their profitability with the adoption of good corporate governance practices.

Staikouras, Agoraki, \& Staikouras, (2007), found out that the bank profitability is negatively linked to the size of the Board of Directors, while the effect of the Board composition is, in most cases, insignificant while positive in all models. Also, ( Praptiningsih, 2009) revealed that only foreign shareholders serving ownership control structures are significantly negatively affected by corporate performance.

\section{METHODOLOGY}

In determining the effect of corporate governance on bank performance; a multiple regression model has been derived and analyzed by the panel data analysis to test the relationship between dependent variables and independent variables of this study. The study used 3SLS estimation and due to the presence of autocorrelation and heteroskedasticity problem, the study relies on the result of GLS analysis.

\section{Empirical Model and Sample Selection}

To test the effect of corporate governance on of bank's performance, several ratios are used to measure the performance of banks. These two most often used are the rates of return on assets (ROA) and the rates of return on equity (ROE). These two measures, ROE, helps investors to measure how investments generate their income while ROA used to measure the efficient of management in using its asset to generate more income. The study used these ratios as dependent variables to analyze the performance of commercial banks in the area of study. Many countries including Kenya have succumbed to these questionable corporate governance policies and unethical practices ${ }^{1}$. That's why this study used a set of independent variables such as Board Size, board composition, number of meetings, number of committees, and size of the audit committee. The study used these independent variables because are the most essential components in corporate governance mechanisms. Most of the previous studies evaluated the relationships between two or three variables with conflicting and inconsistent results. For example, few studies examined how the audit committees have an influence on the banks' performance and came with different result that audit committee has positive but insignificant relationship with performance (Abdulazeez, Ndebel, \& Mercy, 2016). However, this create a gap because banks can have multiple committees but most of the studies failed to address which committee has a significant important to the bank's performance. Therefore; this study will not only measure the number of the committee in the banks but also look on the specific audit committee itself and focus on the number of the member of audit committee in the banks. There are few studies that focused on the size of the audit such as (Pucheta-Martinez, M. C. \& Fuentes, C. D. , 2007) (Afza, T \& Nazir, M. S, 2014). With believing that this will contribute to the board of knowledge and reduce the gap of the future study and will help the directors to take specific action.

Finally, the empirical model of the study also includes two control variables; firm size and leverage. The comprehensive empirical model is as follows:

Model (1):

ROA $=\beta o+\beta 1$ LNBS $+\beta 2$ LNNEDs $+\beta 3$ LNNBM $+\beta 4$ LNNC $+\beta 5$ LNSAC $+\beta 6$ LnTA $+\beta 7$ Lnlv $+\varepsilon_{\text {it }}$ Model (2):

ROE $=\beta 0+\beta 1$ LNBS $+\beta 2$ LNNEDs $+\beta 3$ LNNBM $+\beta 4$ LNNC+ $\beta 5$ LNSAC $+\beta 6$ Lnb $\_s i z e+\beta 7$ Lnlv $+\varepsilon_{\text {it }}$

Where,

ROA and ROE return on asset and return on equity respectively this was derived from the balance sheet of the banks; BS -Board Size; it represents the number of board of directors during the year. NEDs represents board composition this represents the percentage of non-executive director in the banks during the year; and is calculated by taking the number of non-executive director divide by the total number of directors. NBM

\footnotetext{
${ }^{1}$ Dr Tarus Kipchumba (2019) How to overcome challenges in corporate governance: tandardmedia.co.ke/business/article/2001334001/how-to-overcome-challenges-in-corporate-governance
} 


\section{N. S. Soud - N. Aypek 13/4 (2021) 3544-3558}

represents the number of board meetings held during the year. NC represents the Number of the committee during the year. SAC represents the Size of the audit committee during the year.TA represents Total assets and LV represents Leverage, measured by total assets over total equity.

The Sample used in this study was sixteen commercial banks both listed and unlisted. We include those listed and unlisted because the availability of only listed commercial banks in Kenya is few in numbers. Sample data have been collected from 2010 until 2019. The total number of observations is 160 observations. Data were collected from the annual reports of the banks. The statistical method used in this study is panel data analysis. The generalized least square method is reported in this study because the sample data are not normally distributed and the data have either a heteroscedasticity problem, autocorrelation problem, or both. According to (Gujarati, 2003), using a generalized least square method will overcome all these problems.

\section{Hypothesis Development}

The hypotheses of this study are going to be tested to measure the performances of the banks. The study develops the following hypothesis:

H1: The board size has a positive significant impact on the bank performance: the larger the board size the high performance will be.

This study believes that the large board size can have a positive effect on firm financial performance; this is because of diversity in education, exchange of knowledge, experiences, and industry experience, large boards play an important role in developing and enhancing decision outcomes, which could lead to high-quality advice and hence better firm performance (Lehn et al., 2009). Nevertheless, some studies (Dalton et al., 1998: (Hillman \& Dalziel, 2003: Lehn et al., 2009) find that large boards have a positive impact on firm efficiency, consistent with the theory of resource dependency, due to improved relations with external resources (Amy J. Hillman \& Thomas Dlziel, 2003)

H2: The higher ratio of non-executive directors has a positive impact on bank performance.

The second hypothesis proposes that the higher ratio of non-executive directors influences bank performance. The Cadbury report recommended that a minimum of three non-executive members be included in the board of directors who can influence the decision of the board. Non-executive directors are predetermined to provide their independent opinions on business strategies, results, promotions, resources, and standards of conduct. Non-executive directors are the core of good governance. They can supervise the executive directors and they can monitor their acts. Ideally, non-executives should be appointed through a formal process and the board should approve their selection as a whole.

\section{H3: The higher the number of board meetings held in the year has a positive significant on bank performance}

The third hypothesis proposes that the higher the number of board meetings influences banks' performance. There is conflicting empirical evidence of the impact of board meetings on corporate performance. Nevertheless, several important issues have been highlighted regarding the results of past studies which may explain the mixed evidence. There was a consistent argument in the literature as to the nature of the board meetings and board performance. This leads to two distinct schools of thought. Many claims that there is a need for regular meetings from time to time for board members to effectively fulfill their task of setting policies and tracking management (Vafeas, N., 1999). On the other hand, some argued that regular meetings resulted in an excess of managerial time, a rise in the financial burden of travel expenses, and a sitting allowance for members of the board. They conclude by saying that the frequency of high board meetings does not improve performance but does improve the quality of such meetings (Ntim \& Osei, 2011) (Taghizadeh, M. \& Saremi, S. Y. , 2013) (Oyerinde, A. A, 2014). Nonetheless, due to the lack of literature on-board process (including frequency and number of Board meetings) as a variable for board attributes. This research explores the effect of frequent board meetings on Bank performance in Kenya. According to this proposition one among the role of corporate governance, the key tasks are to ensure that the corporation holds regular board meetings.

\section{H4: The higher the number of committees has a positive significant on bank performance}

However, the fourth hypothesis proposes that the board committees can influence bank financial performance. Concerning corporate governance, it applies to committees composed of board members with defined sets of duties. The four most commonly named committees by public companies are the audit committee, the 


\section{N. S. Soud - N. Aypek 13/4 (2021) 3544-3558}

remuneration committee, the nomination committee, and the risk committee. In the fifth hypothesis, the study proposes to examine the importance of the size of the audit committee to see if there is any major influence on company performance. Most of the previous studies they investigate in the audit committee and came up with different results.

\section{H5: The size of the audit committee has a positive significant on bank performance}

The last hypothesis proposes that the size of the audit committee has a positive significance on banks 'performance. In terms of corporate governance, the audit committee is one of the most critical committees that must be available. The key aim behind the audit committee's creation is to enhance the consistency of auditing and the board of directors' questioning. It is described by (Arens A, Elder R, \& Beasley M, 2009) as a group of persons chosen from board members who are responsible for preserving the independence of the auditor. An audit committee is a mechanism for corporate governance that uses non-executive directors as a means of managing and overseeing various management functions, such as internal auditing, risk management, compliance, and financial reporting, and that this purpose requires interference when there is a disagreement about financial reporting issues between executive management and the external auditor. For an audit committee to work efficiently and accomplish its objectives, members must be independent of the executive management, have independence from the executive management, financial awareness, and regularly meet under a well-defined agenda (Zabihollah Rezaee, 2008).

\section{FINDINGS}

\section{Descriptive statistics}

First of all, all variables for Kenya Commercial bank comprises 160 observations except ROA and ROE and this is because we use log variables for all variables used in this study. Secondly, the mean value of ROA, ROE, are $-4.03,-2.26$, respectively. Based on the financial measurement, the mean value of ROE is higher than ROA due to the nature of financial statement components. Frequently, profit used to measure ROE and ROA has the same value but assets value is higher than equity value, which causes ROA to be lower than ROE. For financial measurement, ROA varies more than ROE. The minimum of ROA, ROE, and TE are -9.1, -7.3, and the maximum of ROA, ROE, and TE are -1.2, -1.1, respectively. This indicates that, for financial measurement, $\mathrm{ROE}$ has a higher minimum and maximum ratio than ROA.

Table 1: Descriptive Statistics

\begin{tabular}{|l|l|l|l|l|l|}
\hline Variables & Obs & Mean & St.Dev. & Min & Max \\
\hline Lnroa & 141 & -4.034593 & 1.249466 & -9.058401 & -1.222264 \\
\hline Lnroe & 141 & -2.252567 & 1.02155 & -7.273632 & -1.116163 \\
\hline Lnbs & 160 & 2.176392 & .2060304 & 1.609438 & 2.564949 \\
\hline Lnneds & 160 & -.2475331 & .1374764 & -.8119307 & -.0866478 \\
\hline Lnnbm & 160 & 1.800645 & .4514527 & 1.098612 & 3.496508 \\
\hline Lnnc & 160 & 1.580014 & .271065 & .6931472 & 2.079442 \\
\hline Lnacm & 160 & 1.380629 & .2572721 & .6931472 & 2.197225 \\
\hline Lnb_size & 160 & 24.81251 & 1.097952 & 22.2839 & 26.95281 \\
\hline Lnlv & 160 & 1.756986 & .5953662 & .0000457 & 2.809494 \\
\hline
\end{tabular}

\section{Unit root Test}

Before addressing the appropriate specification of our model, it is important to test whether or not the stationary of variables. We have used different tests to verify the presence of unit root. The first test developed by (Im , Paaran, \& Shin, 2003) allows under the alternative hypotheses autoregressive root heterogeneity. The second, the Levin lin Chu (2002), has as the null hypothesis that all panels contain a unit root, and the alternative hypothesis is that the series is stationary. 
The table above summarizes these tests and we notice that we have mixed variables that mean some variables are stationary at a level such as NC, NBN, ACM, BS, NEDS, and Leverage. And the ROA, ROE and Bank size are stationary at first difference.

Table 2: Unit root test

\begin{tabular}{|c|c|c|c|c|}
\hline \multirow[b]{3}{*}{ Variables } & \multirow{2}{*}{\multicolumn{2}{|c|}{ At level }} & & \\
\hline & & & \multicolumn{2}{|c|}{ At first difference } \\
\hline & LLC & IPS & LLC & IPS \\
\hline lnroa & 0.7266 & 1.8898 & $-5.4432^{* * *}$ & $-3.4800^{* * *}$ \\
\hline Inroe & 1.9771 & 1.6352 & $-3.0340^{* * *}$ & $-4.0348^{* * *}$ \\
\hline $\operatorname{lnbs}$ & $3.3357^{* * *}$ & 0.2580 & $4.5061^{* * *}$ & $-4.9080^{* * *}$ \\
\hline lnneds & 0.2363 & $1.9400^{* * *}$ & $-3.3420^{* * *}$ & $2.3197^{*}$ \\
\hline $\operatorname{lnn} c$ & $-5.7177^{* * *}$ & - & - & $-5.7848^{* * *}$ \\
\hline lnnbm & $5.6827 * * *$ & - & - & $-12.7711^{* * *}$ \\
\hline lnsac & $0.0256^{* *}$ & $-2.3169 * *$ & $-4.5720^{* * *}$ & $-5.9339 * * *$ \\
\hline $\operatorname{lnb} \_$size & -1.4272 & \begin{tabular}{|l|}
-1.5833 \\
\end{tabular} & $-7.5638^{* * *}$ & $-2.7279 * *$ \\
\hline $\operatorname{lnlv}$ & $-5.5290 * * *$ & $1.8309 * *$ & $-7.6802 * * *$ & $-3.4785^{* * *}$ \\
\hline
\end{tabular}

$*{ }^{* *}, * * *$ indicates significance at the $10 \%, 5 \%, 1 \%$, levels

\section{Correlation Matrix}

The table 3 shows the correlation between the different variables included in the study. We notice in the first equation, BS, NC, and Bank size have a positive correlation with ROA. For the second equation, BS has a weak correlation with ROE. On the other hand, NC, Bank size has a positive correlation with both ROA and ROE.

Table 3: Correlation Matrix

\begin{tabular}{|l|l|l|l|l|l|l|l|l|l|}
\hline Inroa & lnroa & lnroe & lnnbs & lnneds & lnnc & lnnbm & lnacm & Lnb_size & lnlv \\
\hline Inroa & 1.0000 & & & & & & & & \\
\hline lnroe & 0.8656 & 1.0000 & & & & & & & \\
\hline lnbs & 0.1329 & 0.0828 & 1.0000 & & & & & & \\
\hline Inneds & -0.1761 & -0.1769 & 0.0635 & 1.0000 & & & & & \\
\hline lnnc & 0.2302 & 0.1793 & 0.1396 & -0.0097 & 1.0000 & & & & \\
\hline lnnbm & -0.0895 & -0.0657 & 0.1679 & 0.1058 & 0.2688 & 1.0000 & & & \\
\hline lnacm & -0.1810 & -0.1665 & 0.3005 & 0.2038 & -0.2168 & 0.0929 & 1.0000 & & \\
\hline Inbanksize & 0.2299 & 0.3216 & 0.4635 & -0.1128 & 0.0991 & -0.1197 & 0.0648 & 1.0000 & \\
\hline lnleverage & -0.4167 & -0.0253 & -0.1873 & 0.0248 & -0.0984 & 0.1389 & 0.1207 & 0.0314 & 1.0000 \\
\hline
\end{tabular}

The table 4 represents the 3SLS where it represents our model. The first column (Model 1) presents the estimation results of ROA, the second (Model 2) presents the estimation results of ROE, respectively.

The 3SLS results show that NEDS has a negative and significant impact on ROA and ROE. On the other hand, $\mathrm{NC}$, has a positive impact on ROA and ROE. The Bank's size has a positive and significant impact. The variable LV has a negative impact on ROA.

Table 4: Three Stage Least Square Result (3SLS)

\begin{tabular}{|l|l|l|}
\hline Variables & ROA & ROE \\
\hline Lnbs & -.6145851 & -.371074 \\
\hline Lnneds & $-1.516092^{* *}$ & $-1.025336^{*}$ \\
\hline Lnnbm & -.1589616 & -.1369926 \\
\hline Lnnc & $\mathbf{1 . 0 1 3 3 1 6 ^ { * * * }}$ & $\mathbf{. 6 2 0 0 4 0 6 ^ { * * }}$ \\
\hline Lnsac & -.3285938 & -.4281703 \\
\hline Lnb_size & $\mathbf{. 3 2 7 8 1 0 1 ^ { * * * }}$ & $\mathbf{. 3 1 6 7 0 2 4 ^ { * * * }}$ \\
\hline Lnlv & $\mathbf{- . 9 6 9 2 0 1 7 ^ { * * * }}$ & -.1026466 \\
\hline
\end{tabular}


N. S. Soud - N. Aypek 13/4 (2021) 3544-3558

\begin{tabular}{|c|c|c|}
\hline _cons & $10.46945^{* * *}$ & $-9.578984^{* * *}$ \\
\hline $\begin{array}{l}\text { *** Single Equation Heteroscedasticity } \\
\text { Tests: }\end{array}$ & $\begin{array}{l}\text { Eq. Inroa : Hall-Pagan LM } \\
\text { Test }\end{array}$ & $\begin{array}{l}\text { Eq. Inroe: Hall-Pagan LM } \\
\text { Test }\end{array}$ \\
\hline P-Value & 0.0557 & 0.0886 \\
\hline $\begin{array}{l}\text { *** Overall System Heteroscedasticity } \\
\text { Tests: }\end{array}$ & \\
\hline Breusch-Pagan LM Test (P-Value ) & \multicolumn{2}{|r|}{0.0000} \\
\hline Likelihood Ratio LR Test & \multicolumn{2}{|r|}{0.0000} \\
\hline Wald Test & \multicolumn{2}{|r|}{0.0000} \\
\hline $\begin{array}{l}\text { *** Single Equation Autocorrelation } \\
\text { Tests: }\end{array}$ & $\begin{array}{l}\text { Eq. lnroa : Durbin-Watson } \\
\text { DW Test }\end{array}$ & $\begin{array}{l}\text { Eq. lnroe: Durbin-Watson } \\
\text { DW Test }\end{array}$ \\
\hline & 0.8380 & 0.8733 \\
\hline${ }^{* * *}$ Overall System Autocorrelation Tests: & & \\
\hline Harvey LM Test & \multicolumn{2}{|r|}{0.0000} \\
\hline R-square & 0.3421 & 0.1830 \\
\hline
\end{tabular}

* Standard errors in parenthesis; ${ }^{* *}$ Statistical significance: ${ }^{*}<.05,{ }^{* *}<.01$

As we explained before the 3SLS estimation detect the Heteroscedasticity and autocorrelation problem, for that reason the study decide to report the result of GLS to avoid this problem.

\section{RESULT.}

The table below includes the results of the effect of corporate governance on banks' performance for ROA and ROE as dependent variables. The variables as corporate governance mechanism of banks' profitability are board size, board composition represented as NEDs, number of board meetings, number of committees, and size of audit committees.

Table 5: Generalized Least Square Result.

\begin{tabular}{|c|c|c|}
\hline Variables & Model 1 & Model 2 \\
\hline $\operatorname{lnbs}$ & $\begin{array}{l}.6097241 \\
(0.264) \\
\end{array}$ & $\begin{array}{l}-.371074 \\
(0.455) \\
\end{array}$ \\
\hline lnneds & $\begin{array}{l}-1.516434^{* *} \\
(0.015) \\
\end{array}$ & $\begin{array}{l}-1.025336^{*} \\
(0.071)\end{array}$ \\
\hline lnnbm & $\begin{array}{l}.1594798 \\
(0.455) \\
\end{array}$ & $\begin{array}{l}-1369926 \\
(0.481) \\
\end{array}$ \\
\hline $\operatorname{lnn} c$ & $\begin{array}{l}1.013897^{* * *} \\
(0.003)\end{array}$ & $\begin{array}{l}.6200406^{* *} \\
(0.045)\end{array}$ \\
\hline lnsac & $\begin{array}{l}-.3293457 \\
(0.365)\end{array}$ & $\begin{array}{l}.4281703 \\
(0.196)\end{array}$ \\
\hline lnb_size & $\begin{array}{l}.3258355^{* * *} \\
(0.000)\end{array}$ & $\begin{array}{l}.3167024^{* * *} \\
(0.000)\end{array}$ \\
\hline $\ln l v$ & $\begin{array}{l}-.9686167^{* * *} \\
(0.000)\end{array}$ & $\begin{array}{l}-.1026466 \\
(0.477)\end{array}$ \\
\hline _cons & $\begin{array}{l}13.86044^{* * *} \\
(0.003)\end{array}$ & $\begin{array}{l}-9.578984^{* * *} \\
(0.000)\end{array}$ \\
\hline
\end{tabular}

$* * *, * * *$ indicates significance at the $10 \%, 5 \%, 1 \%$, levels 


\section{N. S. Soud - N. Aypek 13/4 (2021) 3544-3558}

The table 5 represents the Generalized least Squares where it represents our models without the problem of heteroscedasticity and autocorrelation. The first column (Model 1) presents the estimation results of ROA, the second (Model 2) presents the estimation results of ROE,

\section{- Board Size}

The result shows the negative insignificant impact of board size on firm performance was indicated for Kenya commercial banks, as shown in the table below. Most prior studies that investigated the impact of board size on firm performance found either a negative or a positive relationship. For instance, (Lipton, M., \& Lorsch, J. W., 1992) (Jensen, M. C., 1993) (Yermack, D., 1996) and (Gertner, R. \& Kaplan, S., 1996) argued that reducing board size helps to prevent any free-rider issues or poor teamwork and communications that larger boards can cause. When the board size increase it causes the difficulty of teamwork and communication, and this can reduce the board's ability to monitor management and thereby growing the agency's problem (Eisenberg, T., Sundgren, S., \& Wells, M. T., 1998). When a board has a large size, there are more divergent viewpoints of different directors, which leads to inefficient decision-making and management control. To put it another way, when a board has a large number of members, it is difficult for them to agree on specific decisions, while small boards are more likely to formulate and agree on specific opinions. Small board size can be more effective in controlling management and, as a result, increase shareholder value.

\section{- NEDs}

The result shown in the table above, there was a negative and highly significant impact of NEDs on ROA and little negative significant on ROE at $10 \%$ significant level for Kenya banks. The outcome for Kenyan banks contradicts the monitoring hypothesis of agency theory, which states that having a greater proportion of NEDs on the board adds value to the company by allowing it to make independent decisions and judgments (Cadbury, A., et al., 1992) (Chhaochharia, V. \& Grinstein, Y, 2009). The findings on NEDs are intriguing; however, a negative association between NEDs and firm performance does not necessarily imply that international codes and guidelines on NEDs are incorrect. This could lead to family members dominating boards, as they can lack the requisite experience and skills in professional business matters. Furthermore, NEDs may not be sufficiently independent to adequately fulfill their monitoring function, or they may be compromised by close relationships with managers, rendering them unable to intervene in management decisions.

\section{- $N B M$}

The result shows a negative and insignificant impact of NBM on ROE and ROA for Kenya banks. This goes inconsistent with several researchers that the intensity and frequency of board meetings is a significant instrument for assessing the effectiveness of the board of directors' monitoring and may increase firm performance (Lipton, M., \& Lorsch, J. W., 1992) (Jensen, M. C., 1993). The monitoring function aims to reduce issues with the agency and keeps managers accountable for their actions. This will be accomplished by regular meetings and events to track and address all operational issues undertaken by the board of directors. The board's operations and meetings are key indicators of the Board's effectiveness (Vafeas, N., 1999) (Lipton, M., \& Lorsch, J. W., 1992).

- $\quad N C$

There was a highly significant impact of NC on ROE and ROA. This means that when the number of committees increases in the board, the performance of the banks increases. Board committees are a significant mechanism of the board structure providing independent professional oversight of corporate activities to protect shareholders' interests (Harrison, 1987). Many empirical pieces of evidence supporting the idea that many significant board decisions are taken in board committees and that these decisions have an effect on corporate financial results are few and concentrated in industrialized economies, with a scarcity of evidence from developing countries. It has been proposed that for the board to effectively exercise its strategic and oversight responsibilities, important board committees are needed to support the board's ability to carry out these fundamental responsibilities (Billmoria, D. \& Piderit, S.K, 2017). According to (Kesner, I, 1988), since most board decisions are made at the committee level, board effectiveness is improved by the form and composition of board committees. 
Regardless of board committees' theoretical popularity in various corporate governance literature, few previous studies have linked board effectiveness to the composition and independence of board standing committees, particularly in supporting corporate financial performance and shareholder value maximization (Billmoria, D. \& Piderit, S.K, 2017). Furthermore, several board committee literature has focused on the impact of individual board committees rather than the entire boards standing committees (Newman \& Mozes, 1999) (Sun, J. \& Cahan, S., 2009), thus making it difficult to relate board effectiveness to board standing committees. This study looks at the number of committees on the board of directors and how they affect the bank's performance.

- $A C M$

The result shown in the table above, there was a negative insignificant impact of ACM on ROE and ROA. Many studies show that the size of the audit committee is one of the most important determinants of a company's performance (Pucheta-Martinez, M. C. \& Fuentes, C. D. , 2007) (Afza, T \& Nazir, M. S, 2014). Similar effects have been located by using (V \& Sharma, 2009), who said that the external audit experience of audit committee participants is related to higher company performance. According to (Afza, T. \& Nazir, M. S, 2014), the size of the audit committee has a substantial negative impact on firm results. This is because a larger audit committee is inefficient. An audit committee works efficiently and accomplishes its objectives, members must be independent of the executive management, have independence from the executive management, financial awareness, and regularly meet under a well-defined agenda (Zabihollah Rezaee, 2008).

\section{Control Variable Result}

\section{- Total Asset (Bank size)}

As we explained in the methodology TA is used as a proxy to measure the firm size. In this study, all variables are transformed into the log to reduce their skewness or kurtosis and mitigate the influence of the outlier data points. The GLS result of performance measurement reports a positive and strong statistically significant effect of the bank size on ROA and ROE. This positive result indicates that large firms may benefit from economies of scale and scope (Joh, S. W., 2003). The size of a company reflects its potential to attain economies of scale as well as market power. Furthermore, the bigger a company is, the more likely it is to use economies of scale to create more effective manufacturing processes, which has a positive impact on the company's performance. As a result, large businesses have a better chance of obtaining financing. Large companies are also better able to raise funds internally and access external capital (Short, H., , Keasey, K.,, Wright, M.,, \& Hull, A., 1999).

\section{- Leverage}

The results show a negative and highly significant effect only on ROA: higher levels of debt will cause a decrease in bank performance. To put it another way, the findings of ROA show that the higher the debt level, the lower the ROA. Companies may be carrying more debt as a result of rising operating costs, which reflects their willingness to meet their commitments to pay higher interest rates (Dechow, P. M.,, Sloan, R. G.,, \& Sweeney, A. P., 1996). Increased debt levels can restrict a bank's ability to obtain new credit, resulting in the loss of valuable investment opportunities. With believing that having a lot of debt has a negative impact on the number of dividends paid because companies with a lot of debt can pay lower dividends to prevent having to rely on external financing. Furthermore, high debt levels may imply financial distress, limiting borrowing because banks are hesitant to lend additional funds due to their financial situation, whereas potential investors and current shareholder trust may be affected (Chen, C. J., \& Jaggi, B., 2001) (Stulz, R., 1988).

\section{DISCUSION AND CONCLUSION}

The result of this study found out that NEDs, NBM, and leverage has a negative and significant impact on banks performance, while NC and total asset has a positive significant impact. On the other hand, board size and SAC have a negative and insignificant impact on bank performance. This shows that the only result of NC support the proposed hypothesis regarding the number of committee on bank performance H4. More recent studies (Vo \& Nguyen,, 2014) for Vietnamese firms; (Palmberg, 2015) for Swedish firms, and (Issarawornrawanrch, 2015) for Thai firms found a significant relationship between the proportion of nonexecutive directors and the firm performance. 


\section{N. S. Soud - N. Aypek 13/4 (2021) 3544-3558}

This study is against previous studies (Miller-Millesen, J. L, 2003) (Gales, L. M., \& Kesner, I. F., 1994) (Dalton, D. R.,, Daily, C. M., , Ellstrand, A. E.,, \& Johnson, J. L, 1998) (Lehn, K. M.,, Patro, S.,, \& Zhao, M, 2009), claim that larger boards are better at enhancing firm performance than smaller boards. They argue that in small boards, the CEO's powerful role allows him to circumvent board members' decisions based on their desires, resulting in a rise in agency and, as a result, a decrease in firm performance (Miller-Millesen, J. L, 2003) Furthermore, large boards encourage directors to share highly qualified counsel and provide extra capacity for correlation with various external linkages. Therefore, companies with larger and more diverse boards are more likely to reduce management-shareholder disputes, resulting in higher shareholder returns and thereby better company performance. Also, (PRAPTININGSIH, M.,, 2009) is consistent with this study where board size is insignificant with ROA. Muhammad, Sheila, et.al (2011), found the result of their research that a smaller board size and a higher percentage of block ownership leads to better efficiency of Malaysian banks.

Also, Most of the previous studies show that the higher proportion of NEDs in a board indicates better oversight and therefore decreased agency problems (Fama \& Jensen, 1983) (Shleifer, \& Vishny, 1997), However, previous research (Agrawal, A. \& Knoeber, C. R., 1996) (Bhagat, S. \& Black, B., 1999) (Yermack, D., 1996), has found that companies with higher proportions of NEDs are more likely to have lower performance because NEDs are part-time staff who are unfamiliar with the operations and company market and are unable to comprehend the complexities and challenging situations that face the company. On the other hand, the NBM result is consistent with (Vafeas, N., 1999) (Lipton, M., \& Lorsch, J. W., 1992) believing that the board's operations and meetings are key indicators of the Board's effectiveness. Also, the NC result of this study is agreeing with (Kesner, I, 1988), since most board decisions are made at the committee level, board effectiveness is improved by the form and composition of board committees. The control variables appear to have an extensive and constant effect on banks' performance.

The study revealed that there was an insignificant impact on board size and SAC. This shows both ROA and ROE. Other factors besides the size of the board of directors and the audit committee played a bigger role in the banks' performance. It would be interesting to learn more about these aspects, particularly in terms of board policies and how they are applied. The board members' quality may also influence their performance. The board members' experience, skill, and understanding of the firm will all be crucial factors to examine. It is critical to keep board members accountable for their activities in the areas of openness and accountability, and only those who improve their performance will have their terms renewed. They may be given explicit goals to achieve, and their progress could be monitored against those goals.

The study is limited to sixteen commercial banks in Kenya and is based on data for ten years period from 20102019. Diversifying the sample and lengthening the observation period may result in more consistent results for future research. Other research could be undertaken to discover non-quantitative elements that influence the financial performance of Kenyan commercial banks in addition to the variables utilized in this study.

\section{REFERENCES}

Aanu, O. S., Odianonsen, I. F., \& Foyeke, O. I. (2014). Effectiveness of audit committee and firm financial performance in Nigeria: An empirical analysis. Journal of Accounting and Auditing: Research and Practice, $1-12$

Abdulazeez DA, , NdibeL , \& Mercy AM. (2016). Corporate Governance and Financial Performance of Listed Deposit Money Banks in Nigeria. Journal of Accounting \& Marketing.

Abdulazeez, Ndebel, \& Mercy. (2016). Corporate Governance and Financial Performance of Listed Deposit Money Banks in Nigeria. Journal of Accounting and marketing, 5:1 DOI: 10.4172/2168-9601.1000153.

Afza, T, \& Nazir, M. S. (2014). Audit quality and firm value:A case of Pakistan. Research Jorunal of Applied SciencesvEngineering and Technology, 7(9), 1803-1810.

Afza, T., \& Nazir, M. S. (2014). Audit quality and firm value: A case of Pakistan. Research Jorunal of Applied Sciences Engineering and Technology,, 7(9), 1803-1810. 


\section{N. S. Soud - N. Aypek 13/4 (2021) 3544-3558}

Agrawal, A., \& Knoeber, C. R. (1996). 1996).Firm Performance and Mechanisms to Control Agency Problems between Managers and Shareholders. Journal of Financial and Quantitative Analysis, 31(03), 377-397.

Ahmed, I. A. (2019). Capital Structure, Ownership Structure and Corporate Governance of SMEs in Ghana. Journal of Accounting - Business \& Management,, vol. 26 no. 1 (2019) 45-56.

Alqatamin, R. M. (2018). Audit committee effectiveness and company performance. Accounting and Finance Research, 7(2), 48-60.

Amy J. Hillman, \& Thomas Dlziel. (2003). Boards of directors and firm performance:Intergrating agency and resources dependence perspectives. Academy of Management Review, Vol.29, No. 3, 383-396.

Arena, S., , Kayagil, S. Ö., , \& Aydemir, S. D. (2014). The determinants and effects of corporate governance level: evidence from Istanbul stock exchange. Procedia - Social and Behavioral Sciences:. 10th International Strategic Management Conference, 1061 - 10.

Arens A, Elder R, \& Beasley M . (2009). Auditing and Assurance Services: An Integrated Approach. Pearson.

AYGUN, M., Tasdemir, A., \& Cavdar, E. (2010). Banka Performansi Uzerinde Yonetim Kurulu Buyuklugunun Etkisi. Ataturk University Journal of Economics and Administrative Sciences, Vol.24, No.3, 2010, pp.67-78.

Bebchuk, L., , Cohen, A. , \& Ferrell, A. (2009). What Matters in Corporate Governance? The Review of Financial Studies, , 22, 2, 783-827.

Beyer, A., Cohen, D., A., Lys, T. Z., \& Walther, B. R. (2010). The financial reporting environment: Review of the recent literature. Journal of ccounting and Economics,, 50(2-3), 296-343. doi:10.1016/j.jacceco.2010.10.003.

Bhagat, S., \& Black, B. (1999). The Uncertain Relationship between Board Composition and Firm Performance. The Business Lawyer, ., 921-963.

Billmoria, D., \& Piderit, S.K. (2017). Board committee membership: effects of sex-selected bias. Acad. Manag. J., 37, 1453-1477.

Cadbury, A., Butler, J., Lipworth, S. , Macdonald, N., Smith, A. H., , Brown, S., \& Collum H. (1992). Committee on the Financial Aspects of Corporate Governance. Gee London.

Cheema, K. U., \& Din, M. S. (2013). Impact of Corporate Governance on Performance of Firms: A Case Study of Cement Industry in Pakistan. Journal of Business and Management Sciences,, Vol. 1, No. 4, 44-46.

Chen, C. J.,, \& Jaggi, B. (2001). Association between Independent Non-ExecutiveDirectors, Family Control and Financial Disclosures in Hong Kong. Journal of Accounting and Public Policy,, 19(4), 285-310.

Chhaochharia, V., \& Grinstein, Y. (2009). CEO Compensation and Board Structure. The Journal of Finance,, 64(1), 231-261.

Daily, C. M., Dalton, D. R., \& Ca, A. A. (2003). Corporate Governance: Decades of Dialogue and Data. Academy of Management Review, Vol. 28, No. 3.

Dalton, D. R.,, Daily, C. M., , Ellstrand, A. E.,, \& Johnson, J. L. (1998). Meta-Analytic Reviews of Board Composition, Leadership Structure, and Financial Performance. Journal of Strategic Management, 19(3), 269-290.

Dechow, P. M.,, Sloan, R. G.,, \& Sweeney, A. P. (1996). Causes and Consequences ofEarnings Manipulation: An Analysis of Firms Subject to Enforcement Actionsby the Sec*. Contemporary Accounting Research, 13(1), 1-36.

Dr. Tarus Kipchumba (2019). How to overcome challenges in corporate governance: tandardmedia.co.ke/business/article/2001334001/how-to-overcome-challenges-in-corporategovernance.

Eisenberg, T., Sundgren, S., \& Wells, M. T. (1998). Larger Board Size and Decreasing Firm Value in Small Firms. Journal of Financial Economics,, 48(1), 35-54. 


\section{N. S. Soud - N. Aypek 13/4 (2021) 3544-3558}

Ene, E. E., \& Bello, A. I. (2016). The Effect of Corporate Governance on Bank's Financial Performance in Nigeria. Journal of Business and Management, 2319-7668. Volume 18, Issue 11. Ver. II, PP 99-107.

Fama, E. F., \& Jensen, M. C. (1983). Seperation of ownership and control. The Journal of Law and Economics.

Fodio, M. I., Ibikunle, J., \& Oba, V. C. (2013). Corporate governance mechanisms and reported earnings quality in listed Nigerian insurance firms. International Journal of Finance and Accounting,, 2(5), 279-286. doi:10.5923/j.ijfa.20130205.01.

Gakeri J, K. (2013). Enhancing Kenya's Securities Markets through Corporate Governance: Challenges and Opportunities. International Journal of Humanities and Social Science,, 3, 6, 96-117.

Gales, L. M., , \& Kesner, I. F. (1994). An Analysis of Board of Director Size and Composition in Bankrupt Organizations. .Journal of Business Research,, 30(3), 271-282.

Gertner, R., \& Kaplan, S. (1996). The Value-Maximizing Board.University of Chicago and NBER Working Paper.

Ghaffar, A. (2014). Relationship of Islamic Bank's Profitability with Corporate Governance Practices. European Journal of Business and Management, Vol.6, No.17.

Gujarati, D. (2003). Basic econometrics, viewed on 16 May 2008, <http://imall.ntu. edu.sg/ ProductDetail.asp?ProductID=27477\&categoryName=ECON , accessed $>$.

Harrison, J. (1987). The strategic use of corporate board committees. Organizational approaches to strategy. 30, 109-125.

Hillman, A. J., \& Dalziel, T. (2003). Boards of Directors and Firm Performance: Integrating Agency and Resource Dependence Perspectives. Academy of Management Review, Vol. 28, No. 3.

Im , K., Paaran, M., \& Shin, Y. (2003). Testing for unit roots in heterogeneous panels. Journal of econometrivs, 115(1), 53-74, 2003.

Issarawornrawanrch, P. (2015). The association between board of directors' characteristics and firm performance: Empirical evidence from emerging market of Thailand,. The Journal of Applied Business and Economics, $17,(1): 54-65$.

Jansen, M. C., \& Meckling, W. H. (1976). Theory of the firm: Managerial behavior, agency costs and ownership structure. Journal of Financial Economics, Volume 3, Issue 4, 305-360.

Jensen, M. C. (1993). The Modern Industrial Revolution, Exit, and the Failure of Internal Control Systems. The Journal of Finance,, 48(3), 831-880.

Jesus, S.G. , \& Emma, G.M. (2013). Does Corporate Governance Influence Earnings Management in Latin American Markets? Journal of Business Ethics, 10(6) 851-892.

Joh, S. W. (2003). Corporate Governance and Firm Profitability: Evidence from Koreabefore the Economic Crisis. Journal of Financial Economics,, 68(2), 287-322.

Kesner, I. (1988). Directors' characteristics and committee membership: An investigation of type, occupation, tenure, and gender. Academy of Management Journal,, 31: 66-84.

Lang, M., \& Lundholm, R. (2000). Voluntary Disclosure and Equity Offerings: Reducing Information Asymmetry or Hyping the Stock. Contemporary Accounting Research,, 17(4), 623-669.

Lehn, K. M.,, Patro, S.,, \& Zhao, M. (2009). Determinants of the Size and Composition of US Corporate Boards: 1935-2000. Financial Management,, 38(4), 747-780.

Leuz, C., Nanda, D. , \& Wysocki, P. D. (2003). Earnings Management and Investor Protection: An International Comparison. Journal of financial economics, 69(3), 505-527.

Lipton, M.,, \& Lorsch, J. W. (1992). A Modest Proposal for Improved Corporate Governance. .The Business Lawyer, 59-77. 


\section{N. S. Soud - N. Aypek 13/4 (2021) 3544-3558}

Mahrani, M., \& Soewarno, N. (2018). The effect of good corporate governance mechanism and corporate social responsibility on financial performance with earnings management as mediating variable. Asian Journal of Accounting,, Vol. 3 No. 1, pp. 41-60.

Manning D. I. (2019). Manning, D. I. (2019). Impact of Corporate Governance on Performance of Financial Companies Listed in the NYS. Journal of Finance, Accounting and Management, 10(2), 1-11,.

Mayang Mahrani, \& Noorlailie Soewarno. (2018). The effect of good corporate governance mechanismand corporate social responsibility on financial performance with earning management as mediating variable. Asian journal of Accounting Research, Vol. 3 No. 1, pp. 41-60.

Miller-Millesen, J. L. (2003). Understanding the Behaviour of Non-Profit Boards of Directors: A Theory-Based Approach.Non-profit and Voluntary Sector Quarterly,. 32(4), 521-547.

Musikali, L. M. (2014). The Law Affecting Corporate Governance in Kenya: A Need for Review. Issue 5, Kenya Legal.

Newman, H. A., \& Mozes, H. A. (1999). Does the composition of the compensation committee Infulence CEO Compensation Practice? Financial Management.

Ntim, C. G., \& Osei, K. (2011). The Impact of Corporate Board Meetings on Corporate Performance in South Africa. African Review of Economics and Finance.

Okere, W., \& Ibidunni, O. M. (2019). Corporate Governance and Investment Decisions in Deposit Money Banks in Nigeria. International Journal of Management, Accounting and Economics.

Okwuchukwu; , O., Ezeudu, I. J., \& Patience, O. C. (2015). Does Corporate Governance Influence Banking Sector Performance in Nigeria. International Journal of Economics, Commerce and Management, Vol.III, Issue 10.

Oyerinde, A. A. (2014). Corporate governance and bank performance in Nigeria: Further evidence from Nigeria. International Journal of Business and Management,, 9, 133-139.

Palmberg, J. (2015). The performance effect of corporate board of directors,. European Journal of Law $\mathcal{E}$ Economics, , 40, (2): 273-292.

Paul, G. D., , Ebelechukwu, E. C., , \& Yakubu, S. (2015). Impact of Corporate Governance on Financial Performance of Microfinance Banks in North Central Nigeria. International Journal of Humanities Social Sciences and Education, Volume 2, Issue 1, PP.

PRAPTININGSIH, M.,. (2009). Corporate Governance and Performance of Banking Firms: Evidence from Indonesia, Thailand, Philippines, and Malaysia. Journal of Management and Entrepreneurship,, Vol 11 No 1.pp. 94-108.

Pucheta-Martinez, M. C., \& Fuentes, C. D. . (2007). The impact of audit committee characteristics on the enhancement of quality of financial reporting: An empirical study in the Spanish context. Corporate Governance. An International Review,, 15(6), 1394-1412.

R., Y. Q., Entebang, H., \& A., M. S. (2011). Corporate governance and firm performance in Pakistan: The case of Karachi Stock Exchange (KSE)-30. Journal of Economics and International Finance,, Vol. 3(8), pp. 482491 .

Rashidah Abdul Rahman, \& Fairuzana Haneem Mohamed Ali. (n.d.). Board, audit committee, culture and earnings management: Malaysian evidence. Journal of Managerial Auditing, Vol. 21 No. 7. pp. 783-804.

Ross, S. (1973). The Economic Theory of Agency: The Principal's Problem. American Economic Review,, 63, 134139.

Ruparelia, R. (2016). The evolution of corporate governance and consequent domestication in Kenya. International Journal of Business and Social Science,, 7(5), 153-163.

SALIM, R., , Arjomandi, A., \& Seufert, J.H.,. (2016). Does Corporate Governance Affect Australian Banks' Performance?",. Journal of International Financial Markets, Institutions \& Money. 
Shleifer, , A., \& Vishny, R. W. (1997). A Survey of Corporate Governance. The Journal of the American Finance Association.

Short, H., , Keasey, K.,, Wright, M.,, \& Hull, A. (1999). Corporate Governance: fromAccountability To Enterprise. Accounting and Business Research, 29(4), 337-352.

Smith, C. W., \& Stulz, R. (1985). The Determinants of Firms' Hedging Policies. Journal of Financial and Quantitative Analysis, vol. 20, issue 4, 391-405.

Staikouras, P., Agoraki, M.-E. K., \& Staikouras, C. (2007). The Effect of Board Size and Composition on European Bank Performance. European Journal of Law and Economics.

Stulz, R. (1988). Managerial Control of Voting Rights: Financing Policies and the Market for Corporate Control. Journal of Financial Economics,, 20, 25-54.

Sun, J. , \& Cahan, S. (2009). The Effect of Compensation Committee Quality on the Association between CEO Cash Compensation and Accounting Performance. Corporate Governance: An International Review,, 17, 193-207.

Taghizadeh, M., \& Saremi, S. Y. . (2013). Board of Directors and Firms Performance: Evidence from Malaysian Public Listed Firm. DOI: 10.7763/IPEDR. . 59. 37, pp. 178- 182, http://www.ipedr.com/vol59/037ICEMM2013-P10030.pdf, 03.07.2014.

TANNA, S., Pasiouras, F.,, \& Nnadi, M. (2013). The Effect of Board Size and Composition on the Efficiency of UK Banks. International Journal of the Economics of Business,, Vol. 18, No.3, 2013, pp. 441-462.

V, N., \& S. D. (2009). Former audit partners on the audit committee and internal control deficiencies. The Accounting Review, 84 (2): 559-587.

Vafeas, N. (1999). The Nature of Board Nominating Committees and Their Role in Corporate Governance. .Journal of Business Finance \& Accounting,, 26(1-2), 199-225.

Vo, D., \& N. T. (2014). The impact of corporate governance on firm performance: Empirical study in Vietnam,. International Journal of Economics and Finance, , 6, (6): 1-13.

Yermack, D. (1996). Higher Market Valuation of Companies with a Small Board of Directors. .Journal of Financial Economics,, 40(2), 185-211.

Zabihollah Rezaee. (2008). Corporate Governance and Ethics. John Wiley \& Sons.

Zabria, S. M., , Ahmad, K., \& Wah, K. K. (2016). . (2016). Corporate Governance Practices and Firm Performance: Evidence from Top 100 Public Listed Companies in Malaysia. Journal of economic and finance. : 7th International Economics \& Business Management Conference,,. 